\title{
GEOTECTONIC SIGNIFICANCE OF THE NEOPROTEROZOIC GRANITIC MAGMATISM IN THE ARAÇUAÍ BELT, EASTERN BRAZIL: A MODEL AND PERTINENT QUESTIONS
}

\section{ANTÔNIO CARLOS PEDROSA-SOARES*, CRISTINA MARIA WIEDEMANN**, MARIA LOURDES SOUZA FERNANDES*, LEONARDO FIGUEIREDO DE FARIA ${ }^{* 1}$ AND JULIANA CRISTINA HENRIQUES FERREIRA ${ }^{* 2}$}

\begin{abstract}
RESUMO SIGNIFICADO GEOTECTONICO DO MAGMATISMO GRANITICO NEOPROTEROZOICO DA FAIXA ARACUAI, LESTE DO BRASIL: UM MODELO E QUESTÕES PERTINENTES A Faixa Araçuaí é a parte brasileira do Orógeno Araçuaí-Oeste Congolês. Remanescentes de litosfera oceânica, formados em torno de $816 \mathrm{Ma}$, relacionam-se ao estágio de margem passiva da bacia Araçuaí. Durante o Evento Brasiliano (650-500 Ma), intensa anatexia crustal produziu grande volume de magma granitóide no domínio tectônico internc da Faixa Araçuaí. Cinco diferentes suites granitóides são reconhecidas. A suíte Gl, sintectônica, constitui o núcleo anatético do orógeno. E representada por corpos batolíticos de ortognaisses do tipo S. A suíte G2 é composta por granitóides tipo I, cálcio-alcalinos, sintectônicos. A suíte G3, tarditectônica, compreende corpos graníticos peraluminosos, do tipo S, alojados principalmente em Gl. A suíte G4 consiste de intrusões granitóides tardi a pós-tectônicas, do tipo I com assinatura cálcio-alcalina de alto-K. A suíte G5 compreende plútons graníticos do tipo S, pós-tectônicos. Neste trabalho se propõe um modelo para explicar a origem destas suites granitóides. Ao desenvolvimento da bacia Araçuaî seguiram-se subducção de sua litosfera oceânica, convergência continental e espessamento crustal. O incremento progressivo na temperatura metamórfica, relacionado à ascensão de magmas e espessamento crustal, induziu anatexia regional nas pilhas metassedimentares. Deste processo resultaram, inicialmente, os granitóides Gl a partir da fusão parcial do complexo kinzigítico e, talvez, da Formação Salinas. No estágio tardio, relaciona-se a geração dos granitóides G3 ao alívio do stress compressional. As suites G2 e G4 alinham-se na direção N-S e mostram zonamento de oeste para leste, sugerindo diferentes estágios de maturação do magmatismo cálcio-alcalino. Neste contexto, G2 representaria a raiz de um arco vulcânico continental, relacionado a uma zona de subducção mergulhante para leste. G4 representa as fusões cálcio-alcalinas de alto-K, pós-colisionais, geradas no nível crustal mais profundo. Finalmente, os plútons pós-colisionais da suíte G5 foram gerados e alojados em níveis crustais mais rasos do orógeno.

Palavras-chaves: Orógeno Araçuaí-Congo Ocidental, granitos neoproterozóicos, granitos Brasilianos

ABSTRACT The Aracuaí Belt is the Brazilian counterpart of the West Congo Belt. Both belts compose the Neoproterozoic Aracuaí-West Congo Orogen. Remnants of an oceanic lithosphere, formed at about $816 \mathrm{Ma}$ ago, are related to the passive maroin stage of the Ara? uaf basin. During the Brasiliano Event (650-500 Ma), widespread melting of a pre-existing crust produced a considerable amount of granitoid magma in the internal tectonic domain of the Ara?uaf Belt. Five different granitoid suites can be distinguished. The Gl syn-tectonic suite constitutes the anatectic nucleus of the orogen. It comprises batholitic bodies of S-type orthogneisses. The G2 suite consists of syn-tectonic, I-type, calc-alkalic granitoids. The G3 suite comprises late-tectonic, S-type peraluminous granitic bodies emplaced mainly in the Gl domain. The G4 suite consists of late- to post-tectonic intrusive bodies of I-type, high-K calc-alkalic granitoids. The G5 suite comprises post-tectonic intrusive plutons composed of S-type granites. We propose a model for explaining the origin of these granitoid suites. The development of the Arafuaf basin was followed by the subduction of the oceanic lithosphere, continental convergence and crustal thickening. The progressive increase in the regional temperature related to magma rising and crustal thickening induced widespread partial melting of the metasedimentary piles. The extensive anatexis under high- $\mathrm{H}_{2} \mathrm{O}$-pressure generated $\mathrm{Gl}$ granitoids from kinzigitic gneisses and maybe from the Salinas Formation. At a late stage, the release of the regional pressure may have produced the G3 granites. G2 and G4 granitoid suites show a N-S trend and a west to east zoning, suggesting successive stages of maturation of calc-alkalic magmatism. In this scenario, G2 may represent the root of a continental volcanic arc related to an east-dipping subduction zone. G4 granitoids represent the post-collisional, high-K calc-alkalic melts evolved from the lowermost crust, probably with mantle contributions. Finally, the post-collisional, S-type granites of the G5 suite were generated and emplaced in shallow levels of the orogen.
\end{abstract}

Keywords: Araçuaí-West Congo Orogen, Araçuaí Belt, neoproterozoic granites, Brasiliano granites

INTRODUCTION The Aracuaí (eastern Brazil) and West Congo (southwestern Africa) belts are counterparts of the same Neoproterozoic orogen located between the São Francisco and Congo cratons (e.g., Brito-Neves \& Cordani 1991, Trompette 1994).

The external tectonic domain of the Araçuai-West Congo Orogen makes up an arch-shaped belt that includes the western zone and the northern curvature of the Araçuaí Belt, and the West Congo Belt. The northern segment of the polycyclic Atlantic Metamorphic Belt (Leonardos \& Fyfe 1974) corresponds to the major portion of the internal tectonic domain of the Araçuaí Belt. This tectonic domain also encompasses the distal portion of the Macaúbas Group (Fig. 1). The Brasiliano-Pan-African erogenic plutonism of the Araçuai-West Congo Orogen is confined to the internal tectonic domain of the Ara9uai Belt (cf. Trompette 1994).

The geotectonic significance of the Brasiliano granitic magmatism in the northern sector of the Araguaf Belt is discussed in this paper based on new data and on a concise overview of the regional geologic scenario (Fig. 2). For this purpose, our interpretation is also based on new geologic maps that cover the studied region (Faria 1997, GrossiSadet al. 1997, Pinto et al 1997).

GEOLOGIC SETTING This synthesis focuses on the internal tectonic domain of the northern sector of the Arafuaf Belt (Fig. 2).

The eastern portion of the Guanhaes block and the southwestern border of the Itabuna block represent the ancient gneissie basement reworked during the Brasiliano Event, in the internal tectonic domain of the belt (e.g., Dussin 1994, Barbosa \& Dominguez 1996).

The Juiz de Fora Complex comprises the high grade amphibolite to granulite facies rocks of the polycyclic basement of the Atlantic Belt in Minas Gerais State (cf. Pedrosa-Soares et al. 1994a,b). The Transamazonian and Brasiliano tectonic events are recorded by the Juiz de Fora Complex ( $c f$. Figueiredo \& Teixeira 1996). In the study region, this complex consists of garnet-biotite gneiss, kinzigite (sensu stricto), and graphite-rich gneiss, with minor intercalations of calc-silicate granulite and quartzite (Fig. 2). Widespread signs of migmatization indicate ultrametamorphic conditions in this complex. The available geochronological data are not conclusive, but suggest that the northern Juiz de Fora Complex includes rocks older than the Brasiliano Cycle (synthesis in Faria 1997).

The Macaúbas Group represents a megasequence deposited on a continental passive margin in Neoproterozoic time (cf. Pedrosa-Soares 1995, Uhlein et al 1995, Noce et al 1997). The Salinas Formation represents the Macaúbas Group in the internal tectonic domain of the Araçuaí Belt (Fig. 2). Quartz-mica schist (pelitic graywacke) and quartzose metagraywacke predominate in this formation. Sedimentological, petrographic and geochemical data show that the Salinas Formation is a distal turbiditic deep-sea sand-mud sequence. This formation also includes the Ribeirao da Folha Fades, a typical oceanfloor rock assemblage. This facies consists of metamorphosed volcanic-exhalative sediments (banded iron formation, metachert, diopsidite and massive sulfide) and ocean-floor basalts (amphibolites), intercalated with deep-sea pelites. A Sm-Nd whole-rock isochron yielded an age of $816 \pm 72$ Ma for the magmatic crystallization of the MORB-type protoliths of the ortho-amphibolites of the Ribeirao da Folha Facies (Pedrosa-Soares 1995). The positive $\varepsilon_{\mathrm{Nd}}$ values from 3.4 to 4.8 indicate a depleted mantle source for this MORB-type magmatism. Regional metamorphism took place at about $630 \pm 30 \mathrm{Ma}(\mathrm{Rb}-\mathrm{Sr}$ isochron, five samples of biotite schist; Siga Jr. 1986), when syn-tectonic slabs of ultramafic rocks were thrust over the Ribeirao da Folha Facies, and over the Salinas Formation along the eastern edge of the Guanhães block (Fig. 2). The Ribeirão da Folha Facies and the coeval slabs of ultramafic rocks represent Neoproterozoic oceanic remnants in the Araçuaí Belt (Pedrosa-Soares et al. 1992, 1997).

The continuation of the Salinas Formation along the eastern border of the Guanhães block (Fig. 2) was correlated to the Rio Doce Group by Pedreira et al. (1997). This group is the host unit of various 


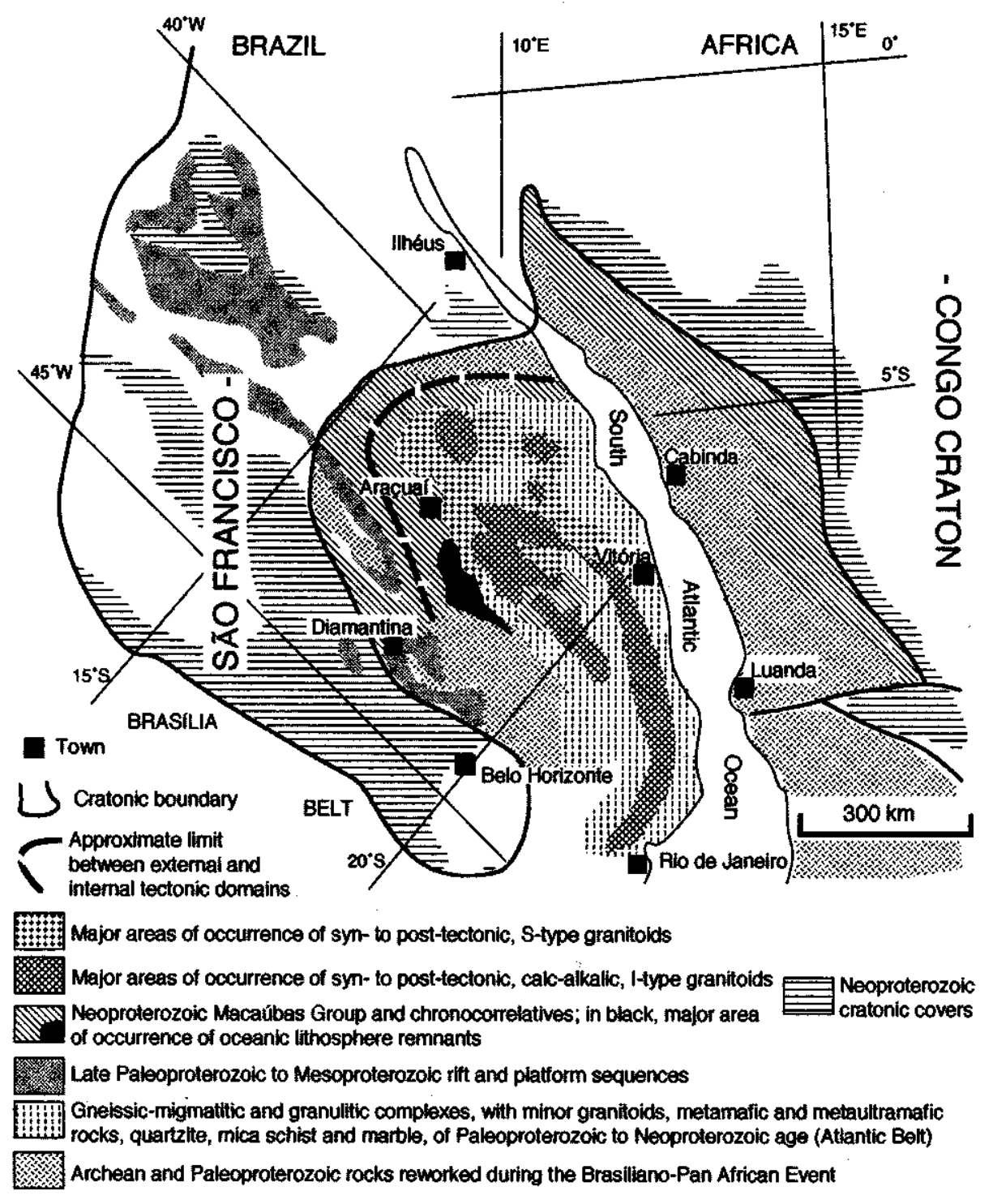

Figure 1 - Major areas of Neoproterozoic to Cambrian granitoids in a geologic sketch map of the Araçai- West Congo Orogen (paleogeographic reconstruction after De Wit et al. 1988; geology after Schobbenhaus et al. 1981, Pedrosa-Soares et al. 1994a, Trompette 1994, Barbosa \& Dominguez 1996, Pinto et al. 1997).

Neoproterozoic granitoid intrusions to the south of the study region (Pinto et al. 1997).

The Jequitinhonha Complex (cf. Pedrosa-Soares et al. 1994a,b) consists of high metamorphic grade quartzite and pelitic schists, containing variable amounts of graphite. Field data suggest that these sediments were deposited on the Juiz de Fora Complex (Faria 1997)

The Capelinha Formation (cf. Grossi-Sad et al. 1997, Noce et al. 1997) includes graphite schist, mica schist, and quartzite deposited on the Salinas Formation and on the Guanhaes block. This formation may be a chronocorrelative of the Jequitinhonha Complex.

During the Brasiliano Event, the regional metamorphic temperature increased from west to east and from north to south in the northern sector of the Araçuaí Belt (Almeida et al. 1978, Costa 1989, PedrosaSoares 1996, Pedrosa-Soares et al. 1996, Carvalho \& Pereira 1997a). Progressive isogrades outline this metamorphic pattern and converge to the nucleus of intense granitic anatexis of the orogen, which will be further considered below.

THE GRANITOID SUITES The granitoid bodies of the northern Araçuaí Belt were grouped into five suites, according to their field relations to host rocks, internal structures, mineralogical compositions, geochemical signatures, radiometric ages, depths of emplacement, and related mineralizations. The geochemical diagrams presented here illustrate data from Pedrosa-Soares et al. (1987, and a paper in preparation), Fernandes (1991), and Faria (1997).

G1 suite The Gl suite makes up the anatetic nucleus of the northern sector of the Araguaf Belt (Fig. 2). It comprises batholitic bodies of tectonicaly foliated, S-type, biotite granitoids. Locally, these orthogneisses enclose minor "rafts" of banded paragneisses and migmatites.

The Gl orthogneisses are fine to coarse grained rocks, with equigranular to porphyroblastic or porphyroclastic textures. The latter consist of porphyroblasts or porphyroclasts of orthoclase in a biotitequartz-feldspathic matrix. Garnet is a common accessory mineral. Sillimanite and cordierite are scarce. The gneissic foliation follows the regional trend of the Aracuaí Belt, indicating metamorphic recrystallization during the main deformation phase. Samples of gneisses from theGl suite yielded metamorphic ages from 655 to $591 \mathrm{Ma}$ (fourRb-Sr isochrons, initial $\mathrm{Sr}$ ratio $\approx 0.708$; Litwinski 1985, Siga Jr. 1986).

These S-type orthogneisses have a granitic composition and a subalkalic to calc-alkalic, peraluminous signature (Fig. 3, 4 and 5). They carry high contents of light REE and very low contents of heavy REE (Fig. 6). The scarce geochemical data also suggest that Gl granites formed at a medium to low crustal level (Fig. 7).

G2 suite The G2 granitoid suite corresponds to the northernmost extremity of the Galileia Intrusive Suite (in the sense of Pinto et al. 
1997). Intrusive bodies composed of tectonicaly foliated granodiorite, granite and tonalite represent this suite in the northern sector of the Araçuaí Belt (Fig. 2). They commonly show a porphyritic texture characterized by orthoclase megacrysts in a biotite-rich, foliated matrix. These rocks are inferred as met aluminous, I-type granitoids by Carvalho \& Pereira (1997b). Regionally, these granitoids present a sharp gneissic foliation and additional ductile deformation features, marking the syn-tectonic character of this suite (e.g., Pinto et al. 1997).
The Galiléia Suite continues for at least $300 \mathrm{~km}$ southward Teófilo Otoni. Nalini Jr. et al. $(1996,1997)$ conclude that this suite is composed of met aluminous, calc-alkalic granitoids, crystallized from hybrid magmas formed by mantle-derived and crustal components. According to Nalini Jr. et al. (1997), the magmatic crystallization of the Galiléia Suite took place at about $594 \pm 6 \mathrm{Ma}$ (upper intercept of an U-Pb discordia diagram; abraded zircons).

G3 suite The G3 suite comprises a series of small coalescent or isolated peraluminous leucogranitic bodies emplaced in larger migma-

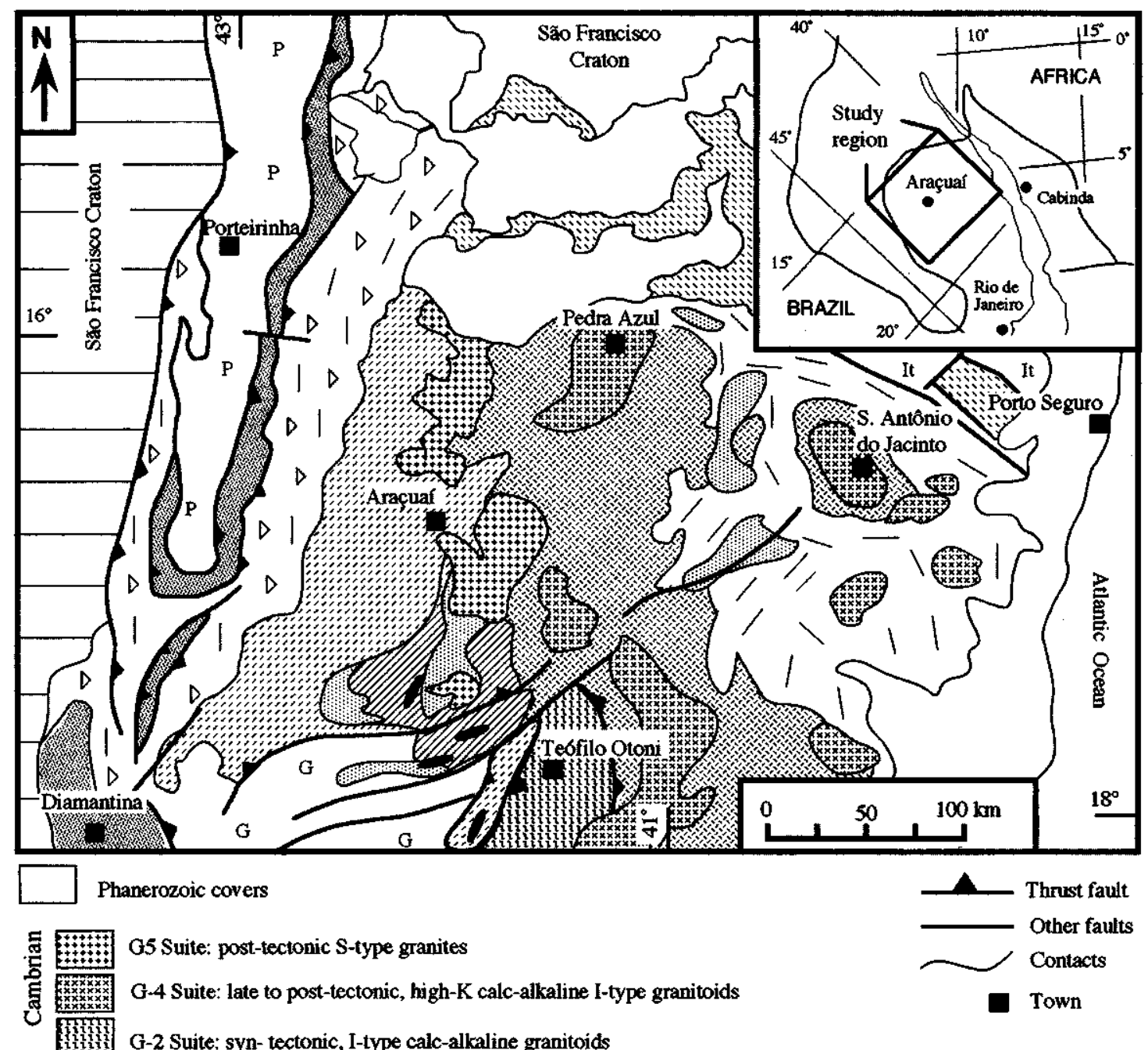

8 G1 Suite: S-type orthogneisses (with minor areas of older units); and G3 Suite: late to post-tectonic S-type granites

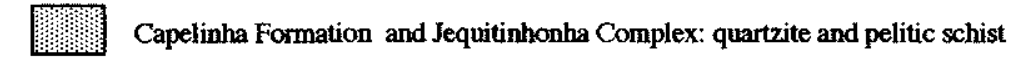

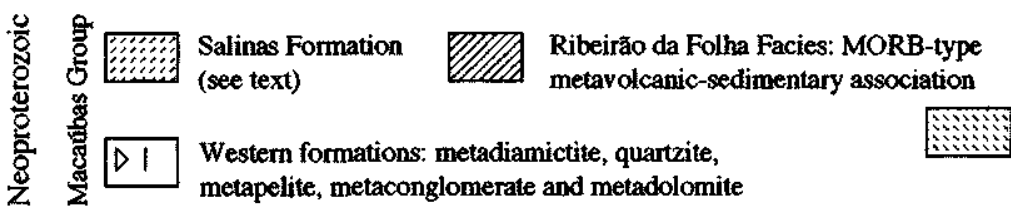

Tectonic slabs of ultramafic rocks (not to scale)

Undivided Macaúibas Group

Neoproterozoic to Juiz de Fora Complex: kinzigitic, biotitic and/or graphitic gneisses and migmatites, with minor Paleoproterozoic 7 intercalations of quartzite, calc-silicate rock and granulite; and undivided areas of granitoid rocks

Mesoproterozoic to 8 (spinhaço Supergroup: quartzite, metaconglomerate, metapelite, and continental acidic to basic Late Paleoproterozoic

Paleoproterozoic to Archean (partially reworked in the Brasiliano Event): Guanhães (G), Itabuna (It), and Porteirinha (P) blocks

Figure 2 - Simplified geological map of the northern sector of the Araçuai Belt (geology compiled from Pedrosa-Soares et al. 1994a, Pedrosa-Soares 1995, Barbosa \& Dominguez 1996, Faria 1997, Grossi-Sad et al. 1997, Pinto et al. 1997). The location of the study region is indicated in relation to Figure 1. 
titic areas mainly in the G1 domain. Their contacts with the enclosing gneisses and migmatites are poorly defined or gradational. A profusion of migmatitic ghost structures as well as nebulitic remnants of metasediments reveals their diatexitic nature.

Garnet, cordierite and/or sillimanite are typical mineral assemblages in these granites. Generally, they form megacrysts disseminated in the leucogranitic matrix, or concentrated along ghost migmatitic banding.

G3 granites represent predominantly peraluminous, subalkalic melts (Fig. 3,4 and 5). In the RlxR2 diagram they plot from the field of late orogenic to syn-collisional granites (Fig. 9). The U-Pb age of $590 \pm 28 \mathrm{Ma}$ (zircons from sillimanite-garnet-biotite migmatite) probably dates the anatectic episode that generated G3 granitoids (Siga Jr 1986). This author also refers to the $\mathrm{Rb}-\mathrm{Sr}$ isochronic age of $586 \pm 13$ $\mathrm{Ma}\left[\left({ }^{87} \mathrm{Sr}{ }^{86} \mathrm{Sr}\right)_{\mathrm{i}}=0.718\right]$ obtained from samples of leucosomatic bands of the same migmatite.

Field relations and geochemical attributes including REE patterns (Fig. 6) reinforce the assumption of consanguinity between G3 granites and the enclosing Gl gneisses and migmatites. Considering their internal structural features, relations to Gl suite, geochemical attributes, and the $\mathrm{U}-\mathrm{Pb}$ and $\mathrm{Rb}-\mathrm{Sr}$ ages, $\mathrm{G} 3$ granites are considered to be late-tectonic, S-type melts.

G4 suite The G4 suite is represented, amongst others, by the Pedra Azul-Medina and Caladao granitoids to the west and the Santo Antônio do Jacinto, Cajuita and Guaratinga to the east (Silva et at. 1987, Fernandes 1991, Celino \& Botelho 1996, 1997, Carvalho \& Pereira 1997b, Faria 1997, Pinto et al. 1997).

The Pedra Azul, Caladao, and Padre Parafso batholiths represent the northern granitoid bodies of the Aimores Intrusive Suite (in the sense of Pinto et al. 1997). This suite includes granitoid batholiths with charnockitic (eg. Padre Parafso Charnockite and Caladao Granite) or enderbitic (e.g. Mangalo Enderbite) nucleus or borders (Pinto et al. 1997, Carvalho \& Pereira 1997b).

According to Silva et al. (1987) and Faria (1997), the Santo Antônio do Jacinto and Cajuita batholiths and the Guaratinga stock, amongst others, constitute the Guaratinga Intrusive Suite, located east of the Aimores Suite. Charnockitic rocks appear to be absent in the Guaratinga Suite.

For the purpose of this paper, granitoids of the Aimores and Guaratinga suites were grouped in the G4 suite. Coalescent intrusive G4 bodies of megaporphyritic granites grading into granodiorites form large polidiapiric structures, with the metamorphic foliation of the host rocks wrapped around them. Their occasional strong border foliation is related to diapiric emplacement at a late to post-tectonic stage. Finer-grained biotite granodiorite, biotite monzo- to syenogranite are late facies intruded as stocks, dikes and in some places form the uppermost portions of the plutons. G4 plutons cut Gl and G3 granitoids as well as the Juiz de Fora Complex (Fig. 2).

Quartz, K-feldspar, sodic plagioclase, biotite and hornblende are the essential minerals of the matrix of G4 porphyritic granitoids. Large phenocrysts of orthoclase/microcline may be very abundant. Allanite, sphene apatite, zircon and magnetite are common accessory minerals. Garnet is scarce or absent. Hypersthene and dark green phenocrysts of perthitic K-feldspar characterize the charnockitic portions. Both porphyritic granitoids and charnockites have the same texture and structure. Green charnockite grading into light-colored granitic facies is regionally a very often feature.

The geochemical data used in this work are from Pedra Azul (Fernandes 1991), Santo Antônio do Jacinto and Cajuita batholiths and Guaratinga stock (Faria 1997). They indicate high-K, calc-alkalic and predominantly met aluminous granites, granodiorites and syeno-diorites (Fig. 3, 4 and 5). REE signatures show a consistent pattern for Pedra Azul, Santo Antônio do Jacinto and Cajuita batholiths and the Guaratinga stock (Fig. 6). These magnetite-series, I-type granitoids were originated in the lowermost continental crust with probable mantle contributions (Fig. 7). Dark-colored microgranular enclaves have dioritic to tonalitic compositions. Further geochemical attributes suggest that G4 suite represents a late-orogenic phase of the post-collisional stage (Fig. 8 and 9). In fact, all G4 plots in Figure 8 fall within the post-collisional field of Pearce (1996).

Siga Jr. (1986) presented a Rb-Sr age of $575 \pm 10 \mathrm{Ma}$ [(hole-rock isochron, initial $\mathrm{Sr}$ ratio $=0.7064$ ) for the magmatic crystallization of the Santo Antônio do Jacinto batholith. Faria (1997) obtained the $\mathrm{Rb}-\mathrm{Sr}$ isochronic age of $582+16 \mathrm{Ma}$ (initial $\mathrm{Sr}$ ratio $=0.7067$ ) from six samples of fine-grained, magnetite-allanite granite of the Guaratinga stock. This age dates the magmatic crystallization of this stock.

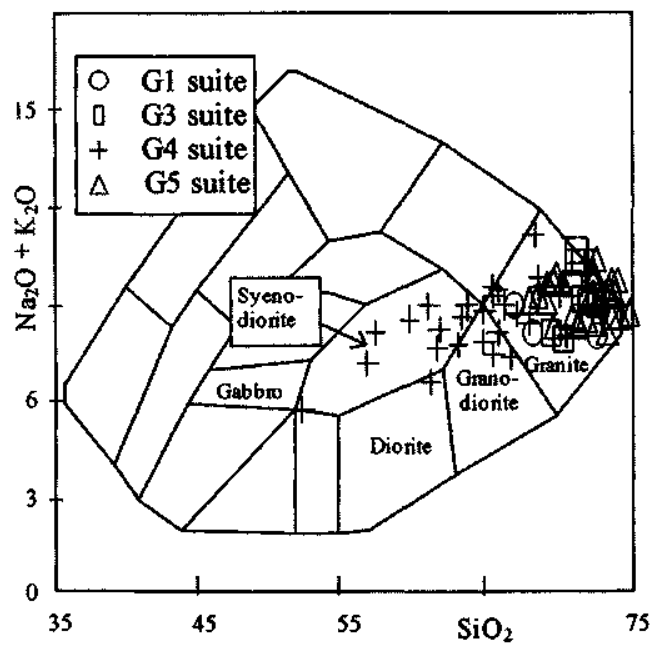

Figure 3 - Classification of granitoid samples from the Araçuai Belt in the TAS diagram of Cox et al. (1979, adapted for plutonic rocks by Wilson 1989).

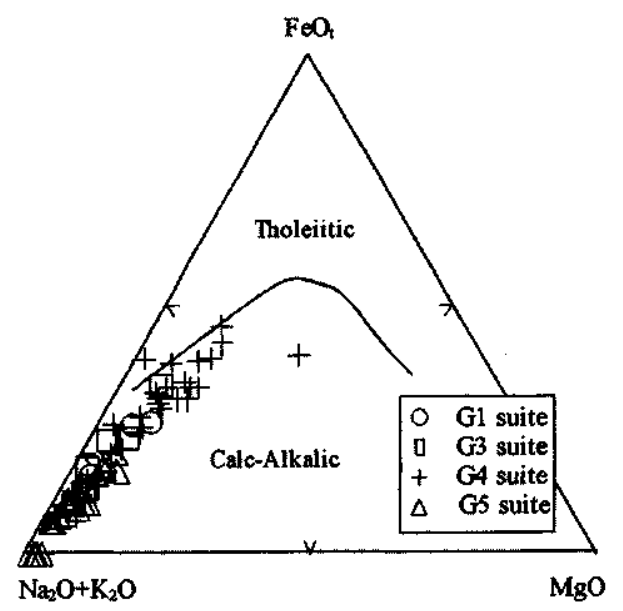

Figure 4 - Distribution of granitoid samples from the Araçuai Belt in the AFM diagram oflrvine \& Baragar (1971).

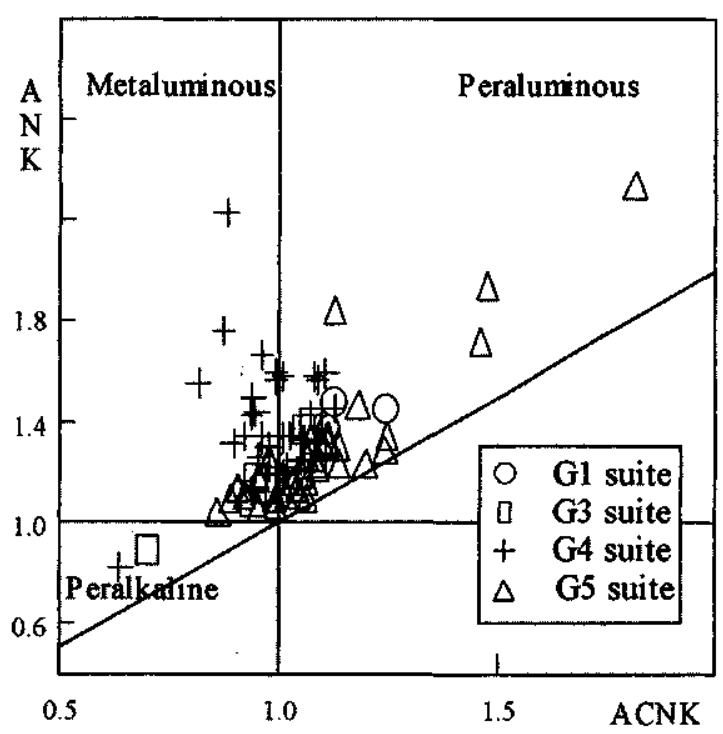

Figure 5 - Distribution of granitoid samples from the Araçuai Belt in the alumina saturation diagram (cf. Shand 1943). 
Structural features, geochemical data and ages of magmatic crystallization are strong evidence that G4 granitoids represent late to post-tectonic melts, emplaced during the post-collisional stage of the orogen.

The southern part of the G4 suite was interpreted by Campos Neto \& Figueiredo (1995) as representative of the "pre-collisional" granitoids of the Rio Doce Orogeny (560-530 Ma). However, the geochronological data here synthesized contradict this supposition.

G5 suite Det alled studies on G5 granitoids, their residual pegmatites and associated tungsten mineralizations are found in CorreiaNeves et al. (1987), Pedrosa-Soares et al. (1987, 1990), Monteiro et al. (1990), Pedrosa-Soares \& Oliveira (1997) and Pedrosa-Soares 1997a,b).

The G5 suite crops out along the western limit of the Salinas Formation (Fig. 2) and comprises balloon-like, post-tectonic intrusive plutons. They are the source of a myriad of lithium- and/or tourmaline-rich pegmatites. The plutons are zoned and contain biotite-granite centers grading into two-mica or muscovite-garnet leucogranites towards their upper borders. The cupolas of the intrusions consist of residual pegmatoid granite. Xenoliths of the host rocks are commonly found in the outer parts of the intrusions. The plutons forced the regional schistosity to accommodate around them, forming post-tectonic curvilinear structures clearly detected in aerophotographs and satellite images.

Biotite granite has fine to medium-grained equigranular texture, grading locally to subporphyritic texture with K-feldspar phenocrysts. Its essential composition is very simple, consisting of quartz, K-feldspar, sodic plagioclase and biotite. Scarce accessory minerals are zircon, apatite and ilmenite. Leucogranites are deuteric metasomatic products of biotite granites (Pedrosa-Soares et al. 1987). Towards the upper portions of the plutons, muscovite gradually replaces biotite and microcline, generating fine-grained two-mica and muscovite-garnet leucogranites. Small crystals of garnet are also products of this metasomatic process. Albitization is absent or incipient, being more important in the cupolas where minor saccharoidal albite-tourmaline granite is associated to pegmatoid granite. The last mentioned is made up of graphic intergrowth of coarse-grained perthite and quartz, and accessory minerals such as black tourmaline, garnet, albite, apatite, beryl and biotite.

G5 granites (Fig. 3) are predominantly peraluminous (Fig. 5) with $\mathrm{K}_{2} \mathrm{O} / \mathrm{Na}_{2} \mathrm{O}$ ratios close to 1 . The $\mathrm{REE}$ diagrams reveal a wide range of variation related to the metasomatic processes that affected these granites (Fig. 6). Compared to the other studied suites, G5 suite derived from shallower crustal melts (Fig. 7). The $(\mathrm{Y}+\mathrm{Nb})$ versus $\mathrm{Rb}$ as well as R1-R2 diagrams are consistent with post-collisional setting (Fig. 8 and 9).

Mineral associations of contact metamorphism and mineralization of pet alite instead of spodumene in some residual pegmatites indicate depths of emplacement between 12 to $6 \mathrm{~km}$ (Pedrosa-Soares et al. 1987; Monteiro et al. 1990).

The $\mathrm{Rb}-\mathrm{Sr}$ age of $525 \pm 30 \mathrm{Ma}$ dates the post-tectonic magmatic crystallization of G5 granites (Siga Jr. 1986; whole-rock isochron, five samples of biotite granite, initial $\mathrm{Sr}$ ratio $=0.711$ ). This high initial ${ }^{87} \mathrm{Sr}{ }^{86} \mathrm{Sr}$ ratio also indicates that G5 granites are S-type of the ilmenite series.

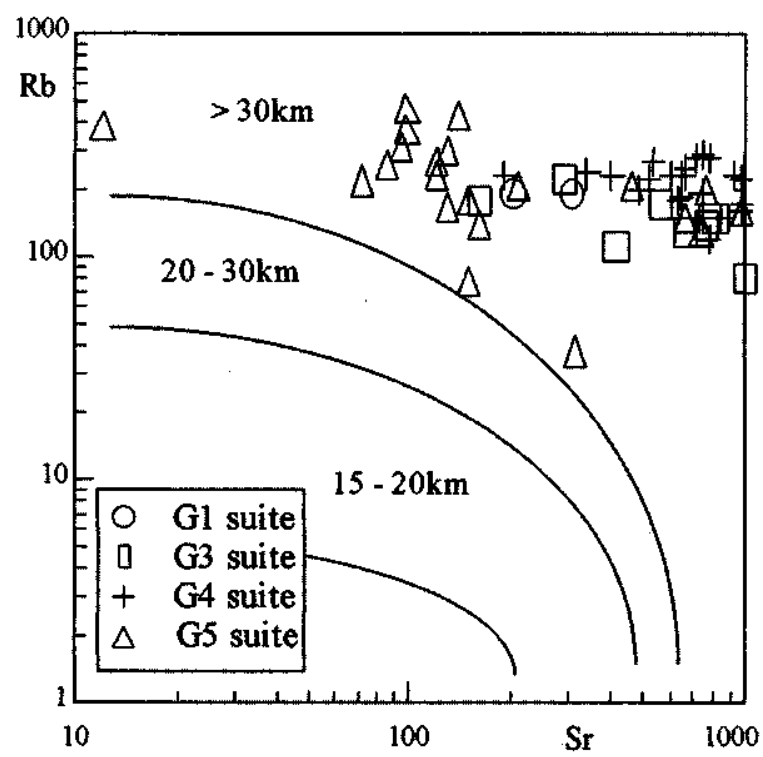

Figure 7 - Distribution of granitoid samples from the Araguai Belt in the $\mathrm{Sr}$ versus Rb diagram ofCondie (1973), (in $\mathrm{km}$, depths of magma generation).
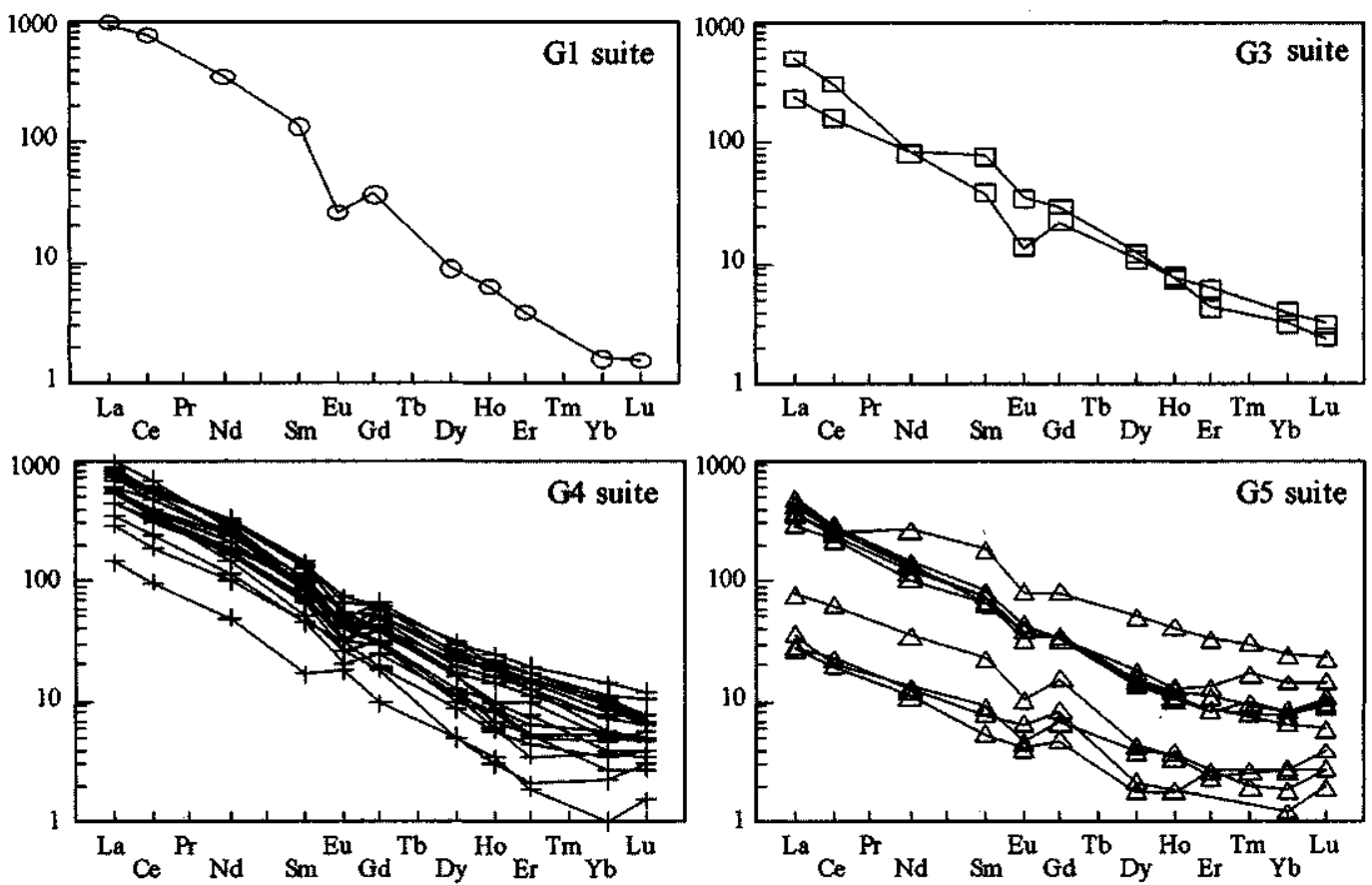

Figure 6 - Rare-earth element patterns (chondrite normalized) of granitoid samples from the Araçuai Belt. 


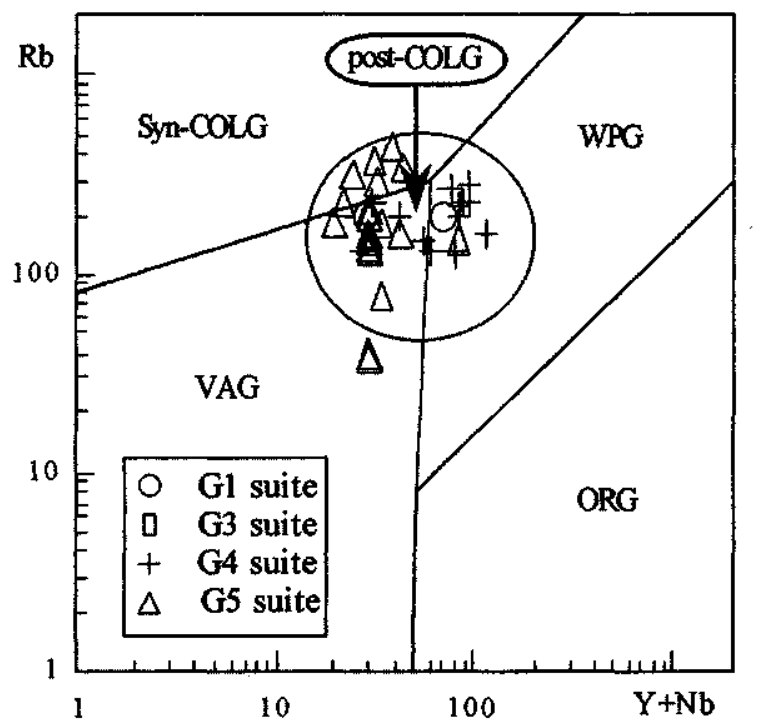

Figure 8 - Distribution of granitoid samples from the Araçuai Belt in the $Y+N b$ versus $R b$ diagram of Pearceet al. $(1984$, modified by Pearce 1996). Tectonic settings of granitoid generation: Syn-COLG, syn-collision; Post-COLG, post-collision; VAG, volcanic arc; WPG, within plate; ORG, ocean ridge.

TECTONIC INTERPRETATION OF THE GRANITOID SUITES Granitoids displaying penetrative tectonic foliation crystallized during pre-collisional and/or collisional stages of the orogenic evolution. The former stage refers to the accretionary or subductionrelated orogen (sensu stricto), that may be followed by a subsequent continent-continent, arc-continent or arc-arc collision.

Pre-collisional generation of normal calc-alkalic, I-type granitoids indicates development of volcanic arcs in oceanic or continental active margin settings. Such granitoids usually form by mantle asthenosphere melting involving a subduction component. Interactions of the mantle-derived magmas with melts formed by anatexis of continental crust (hybridization) may be very significant in continental active margins (e.g., Pitcher 1993, Cobbing 1996, Pearce 1996).

The syn-collisional stage is linked to the process of crustal thickening, generally by the underthrusting of one crustal slab beneath another, after ceasing the subduction of oceanic crust (Harris et al. 1986). The generation of syn-collisional granitoids results from extensive subduction of terrigenous sediment into the mantle, or incorporation of crustal melt into the mantle wedge. Generally, collisional settings involve a continent and an oceanic or a continental volcanic arc, or two continents that were separated by insufficient oceanic crust to generate a volcanic arc before the collision (e.g., Pearce 1996). The syn-tectonic increase of temperature, due to the ascent of magmas and crustal thickening, triggers partial melting of recycled sediments by ultrametamorphic anatexis, resulting in the extensive formation of S-type orthogneisses.

Post-collisional granitoids form some time after ceasing the collision stage itself, and are generally linked to rapid, post-closure uplift and/or to the subsequent collapse of the orogen (e.g., Harris et al. 1986, Pitcher 1993, Pearce 1996). Post-collisional granitoids generally show no penetrative, ductile tectonic foliation, forming roughly circular plutons with the pre-existing regional structures deflected and accomodated around them. Their foliated borders result from diapiric ascent combined or not to the latest imprints of the regional compressional stresses. They also constitute autochthonous to parautochthonous bodies enclosed by migmatites (e.g., Cobbing 1996). These anatectic bodies are generally isotropic, but incipient tectonic foliation may be present. In fact, the collision/post-collision boundary is difficult to identify precisely because of its gradational and diachronic nature from place to place in the orogen. Thus, the origin of post-collisional granitoids (sensu lato) takes place from the late-tectonic (orogenic) to post-tectonic (orogenic) phases. High-K calc-alkalic, I-type granite to tonalite (the so-called Caledonian I-type in Pitcher's classification), as well as the peraluminous, subalkalic to alkalic S-type leucogranite are usually post-collisional granitoids (Pitcher 1993, Roberts \& Clemens 1993, Pearce 1996). Also, some

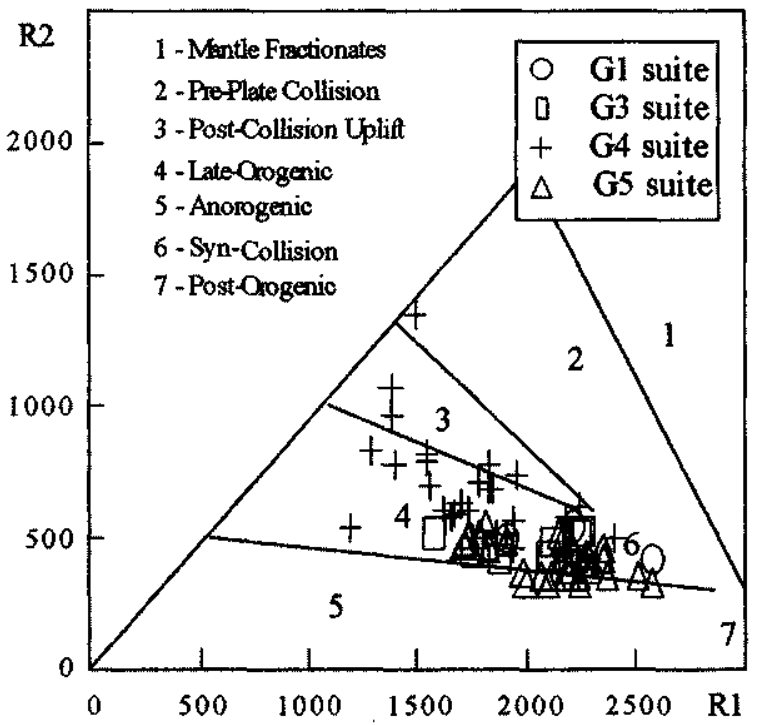

Figure 9 - Distribution of granitoid samples from the Araçuai Belt in the R1xR2 diagram of De La Roche et al. (1980, modified by Debon \& Le Fort 1983).

A-type granitoids may be post-collisional instead of anoroeenic (Eby 1992).

There are two main geotectonic scenarios where the high-K calcalkalic, I-type granitoids may be generated (Pitcher 1993, Roberts \& Clemens 1993, Cobbing 1996, Pearce 1996): a) in continental arc settings similar to that of the Andes by the crustal contamination of mantle-derived magmas; and b) the post-collisional settings where melting of the source rocks occurs as a consequence of decompression subsequent to crustal thickening, followed by mantle upwelling and underplating of the lower crust by mafic magmas. Roberts \& Clemens (1993) suggest "that high-K, I-type magmas can be derived only from the partial melting of hydrous calc-alkalic to high-K calc-alkalic, mafic to intermediate meta-igneous rocks in the crust", instead of being generated by the direct interaction of mantle and crustal magmas. Nevertheless, Roberts \& Clemens' model equally involves heating of the lower continental crust by underplating and/or intraplating of mafic magma.

As cited above, G1, G3 and G5 suites are composed of S-type granitoids, whereas G2 and G4 suites comprise I-type ones. In relation to the regional ductile foliation, Gl and G2 are syn-tectonic suites, whereas G3 and G4 are late to post-tectonic, and G5 is a post-tectonic suite.

In general, the progressive increase of the regional temperature is related to both magma rising (in particular during the pre-collisional stage) and crustal thickening (especially during the collisional stage).

The regional metamorphic grade increases from west to east and from north to south in the Araçuaí Belt (Almeida et al. 1978, Costa 1989, Pedrosa-Soares 1996, Pedrosa-Soares et al. 1996, Carvalho \& Pereira 1997a), and from east to west in the West Congo Belt (Trompette 1994). This pattern depicts a converging nucleus for progressive metamorphic temperatures, located to the north of the $20^{\circ}$ parallel in eastern Brazil (Fig. 1). In the field, this nucleus is delineated by increasing migmatization of the regional gneisses, culminating to the appearing of large masses of autochthonous leucogranites rich in peraluminous minerals such as almandine garnet, cordierite and/or sillimanite.

The alignment of the G1 batholiths is roughly parallel to the distribution of regional metamorphic isogrades and represents the convergence nucleus with metamorphic temperatures decreasing away from it. It is thought that extensive anatexis under high- $\mathrm{H}_{2} \mathrm{O}$-pressure conditions generated G1 granitoids from kinzigitic gneisses, and maybe from the Salinas Formation. These granitoids display the regional gneissic foliation, indicating that they underwent the main deformation phase of the collisional stage. Nevertheless, the production of S-type melts could have begun during the pre-collisional stage.

The G2 suite comprises the foliated, I-type granitoids known in the northern sector of the Araçuaí Belt (Fig. 2). The penetrative tectonic foliation of these granitoids is an evidence that they underwent the main 
deformational phase of the collisional stage, but they could be formed in the pre-collisional stage. The lack of geochemical data precludes a more precise interpretation. Considering the regional scenario and the available data from the southern prolongation of this suite, we suggest that G2 calc-alkalic granitoids may represent the root of a continental volcanic arc related to the consumption of a Neoproterozoic oceanic crust.

At a late erogenic stage the release of the regional pressure may have produced the homogeneous G3 leucogranites by anatexis of the Gl orthogneisses.

The high-K calc-alkalic, I-type G4 granitoids are late to post-tectonic intrusions along the main anatectic nucleus of the orogen. They clearly cut $\mathrm{G} 1, \mathrm{G} 2$, and $\mathrm{G} 3$, representing post-collisional partial melts originated at the lowermost crustal levels (Fig. 7, 8). The origin of G4 granitoids is linked to direct interactions of crustal melts and mantle components. Net veined and pillow-like structures, formed by the interfingering between megaporphyritic granites and more mafic contrasting magmatites, are evidence of magma mingling and/or mixing processes in their generation. Their dark microgranular enclaves show typical magmatic textures with the foliation parallel to the border, mantled feldspars and large rounded quartz as xenocrysts, as well as acicular apatites pointing towards the evidence of interaction of two contrasting magmas. Initial ${ }^{87} \mathrm{Sr} /{ }^{86} \mathrm{Sr}$ values around 0.706 suggest an origin from partial melting of lowermost crust with possible restricted mantle contribution.

The G5 granites were emplaced at higher crustal levels ( $c a$. 6 to 12 $\mathrm{km})$. These granites represent S-type melts evolved from shallower crustal levels than those where G1, G3 and G4 granitoids were formed (Fig. 7). The post-kinematic character in relation to the regional tectonic structures and the $\mathrm{Rb}-\mathrm{Sr}$ age $(\sim 525 \mathrm{Ma})$ are the best evidence that G5 suite record the post-orogenic (relaxation) phase of the orogen.

A MODEL AND SOME PERTINENT QUESTIONS Based on geochronological and $\mathrm{Sr}$ isotopic data, Siga Jr. (1986) proposed a Neoproterozoic ensialic evolution for the Arafuaf-West Congo Orogen. Following this work, Pedrosa-Soares \& Siga Jr. (1987) suggested that the generation of the G5 granitoids was related to an A-type subduction. At that time, oceanic remnants were unknown in the Araçuaí Belt and the knowledge on the described I-type granites was very poor.

The characterization of Neoproterozoic oceanic remnants in the Araguai Belt appears in Pedrosa-Soares et al. (1992). Considering the MORB-type signature of the Ribeirao da Folha Facies, Pedrosa-Soares (1995) proposed a B-type subduction model for the evolution of the Araçuaí Belt. The remnants of oceanic lithosphere found in this belt are evidence that a branch of the Neoproterozoic Adamastor-Brazilide Ocean (Dalziel 1997) developed between the São Francisco paleopeninsula and the Congo paleocontinental region at about $816 \mathrm{Ma}(\mathrm{Pe}-$ drosa-Soares et al. 1997).

Moreover, Correa-Gomes \& Oliveira (1997) proposed that at about $1000 \mathrm{Ma}$ an astenospheric plume begun to act beneath the AraguafWest Congo region. This plume would have induced the process of continental rifting followed by oceanic spreading, required to allow for the deposition of the passive margin megasequence of the Macaubas Group and its MORB-type volcanism.

The proposal of this work to explain the origin of the granitoid suites found in the Araçuaí Belt will be summarized thereafter (Figs. 1 and 2):

- The development of the Araçaí ocean basin would be followed by the subduction of the oceanic lithosphere, continental convergence and crustal thickening.
- From pre-collisional to collisional stages, the progressive increase in the regional temperature related to magma rising and crustal thickening induced widespread partial melting of metasedimentary piles. This extensive anatexis generated the G1 granitoids that underwent the main deformation phase and became orthogneisses. At a late stage, the release of the regional pressure may have produced the homogeneous $\mathrm{G} 3$ granites by anatexis of the G1 orthogneisses.

-The G2 and G4 granitoid suites show a N-S trend and a west to east zoning, suggesting successive stages of calc-alkalic magmatism related to the maturation of a magmatic arc. In this scenario, the G2 (Galiléia) suite may represent the root of a continental volcanic arc related to an east-dipping subduction zone. In fact, the oceanic remnants of the Araçuai Belt and the northern segment of the G2 suite show analogous positions, providing further evidence for the proposed Btype subduction process. G4 granitoids clearly cut G1, G2, and G3 suites, and represent the post-collisional, high-K calc-alkalic melts evolved from the lowermost crust with mantle contributions.

- Finally, the post-collisional, S-type, intrusive G5 granites were generated, by anatexis of Haralyi \& Hasui 1982, Ussami \& Sa 1993) indicate that these granites are only found in the thickest crustal zone preserved in the Aracuaí Belt. This may explain the apparent contrasting position of the G5 suite in relation to the west to east zoning shown by the $\mathrm{G} 2$ and $\mathrm{G} 4$ suites.

Towards the south, the latest closure of the orogen is possibly recorded by the calc-alkalic granitoids of the Espfrito Santo - Rio de Janeiro region (Wiedemann 1993, 1996, Campos-Neto \& Figueiredo 1995).

We would like to finalize raising with some questions for further investigation on the proposed model, such as: -Considering that G2 (Galiléia) suite follows over $300 \mathrm{~km}$ to the south, where are the corresponding Neoproterozoic oceanic remnants southward the study region? The amount of erogenic calc-alkalic plutonism in the Ara^uafWest Congo Orogen is expressive (Fig. 1). Extensive generation of I-type, calc-alkalic granitic melts implies that a reasonably large amount of oceanic lithosphere was consumed. Therefore, we presume that sufficient oceanic spreading took place in the Araguaf basin. On the other hand, the "cratonic bridge" that linked the São Francisco and Congo cratons would have constrained the opening of the ArafuafWest Congo basin (cf. Pedrosa-Soares et al. 1992, Trompette 1994). Could this problem be solved by the contemporary opening of the Paramirim (Schobbenhaus 1996) and Sangha (Trompette 1994) aulacogens in Neoproterozoic time?

- Two suites of foliated granitoids are recognized. The Gl and G2 suites respectivelly consist of S-type and I-type orthogneisses. Both suites may include pre-collisional and/or syn-collisional granitoids. Syn-collisional granites may be formed by processes involving two continents that were separated by insufficient oceanic crust to generate a volcanic arc before the collision. Could this be the case of the studied region?

Acknowledgments Our gratitude to the Brazilian research agencies FINEP (project 1655-FUNDEP), CNPq, FAPEMIG and Pro-Reitoria de Pesquisa-UFMG for financial support. We are also grateful to the technical staff of CPMTC-IGC-UFMG for providing geochemical analysis. A. C. Pedrosa-Soares thanks Carlos Maurfcio Noce (UFMG) and Claiton Piva Pinto (CPRM-BH) for discussions on geochronological, geologic and geotectonic aspects. We thank two anonymous reviewers for their suggestions.

\section{References}

Almeida, F.F.M. de; Hasui, Y.; Rodrigues, E.P.; Yamamoto, J. 1978. A Faixa de Dobramentos Araçuaí na região do Rio Pardo. In: SBG, Congr. Bras. Geol., 30, Recife, Anais, 1:270-283

Barbosa, J.S.F. \& Dominguez, J.M.L. (coord.) 1996. Geologia da Bahia: texto explicativo para o mapa geologico ao milionesimo. Salvador, Brazil, Secretaria da Industria Comercio e Mineragao, Superintendencia de Geologia e Recursos Minerals, 400 p.

Brito-Neves, B.B. \& Cordani, U.G. 1991. Tectonic evolution of South American during the Late Proterozoic: Precamhrian Res., 53: 23-40

Campos-Neto, M. C. \& Figueiredo, M. C. H. 1995. The Rio Doce Orogeny, South-eastern Brazil. J. South Amer. Earth ScL, 8: 143-162

Carvalho, J.B. \& Pereira, L.M.M. 1997a. Metamorfismo das rochas supracrustais da porção leste do Estado de Minas Gerais. In: SBG-Nucleo Minas Gerais, Simp. Geol. de Minas Gerais, 9, Ouro Preto, Anais, 101-102

Carvalho, J.B. \& Pereira, L.M.M. 1997b. Caracterização petrológica das rochas graníticas e charnockíticas da porção leste do Estado de Minas Gerais, baseada em dados petrograficos. In: SBG-Núcleo Minas Gerais, Simp. Geol. de Minas Gerais, 9, Ouro Preto, Anais, 98-100

Celino, J.J. \& Botelho, N.F. 1997. Granitoid suites in the southernmost State of Bahia, NE Brazil. In: SBG, Int. Symp. on Granites and Associated Mineralizations, 2, Salvador, Extended Abstracts, 103-105

Celino, J.J. \& Botelho, N.F. 1996. Granitóides do extremo sul da Bahia e nordeste de Minas Gerais: estudo preliminar. In: SBG, Congr. Bras. Geol., 39, Salvador, Anais, 6: 384-386

Cobbing, J. 1996. Granites - an overview. Episodes, 19: 103-106

Condie, K.C. 1973. Archean Magmatism and Crustal Thickenning. Geol. Soc. Amer. Bull., 84: 2981-2992

Correa-Gomes, L.C. \& Oliveira, E.P. 1997. O enxame radial gigante de diques maficos da província Bahia-Congo: implicates geológicas e tectonicas da presen9a de uma pluma mantelica na interface America do Sul-Africa, 1,0 Ga atras. In: SBG-Nucleo Brasilia, Simp. Nac. Estudos Tectonicos, 6, Pirenópolis, Anais, 52-55

Correia-Neves, J.M.; Pedrosa-Soares, A.C.; Marciano, V.R.P.O.; Monteiro, R.L.B.P.; Fernandes, M.L.S. 1987. Granitoids and pegmatites from the northern of the Eastern Brazilian Pegmatite Province. In: SBG, Int. Symp. on Granites and Associated Mineralizations, 1, Salvador, Excursions Guides, 125-144 
Costa, A.G. 1989. Evolucao petro!6gica para uma sequencia de rochas metamdrficas regionais do tipo baixa presSão na regiao de Itinga, NE de Minas Gerais. Rev. Bras. Geociências, 19: 440-448

Cox, K.G.; Bell, J.D.; Pankhrust, R.J. 1979. The interpretation of igneous rocks. London, George, Alien and Unwin, $450 \mathrm{p}$

Dalziel, I.W.D. 1997, Neoproterozoic-Paleozoic geography and tectonics: review, hypothesis, environmental speculation: Geol. Soc. Amer. Bull, 109: 16-42

De La Roche, H.; Leterrier, J.; Grand-Claude, P. 1980. A classification of volcanic and plutonic rocks using R1-R2 diagrams and major element analysis - its relationships and current nomenclature. Chem. Geol., 29: 183-210

De Wit, M.; Jeffery, M.; Bergh, H.; Nicolaysen, L. 1988. Geological Map of Sectors of Gondwana, reconstructed to their disposition at about 150 Ma, scale 1:10.000.000. Tulsa, USA, American Association of Petroleum Geologists and Johannesburg, South Africa, University of Witwatersrand

Debon, F. \& Le Fort, P. 1983. A chemical-mineralogical classification of common plutonic rocks and associations. Trans. Royal Soc. Ed. Earth Sci., 73: 135-149

Dussin, I.A. 1994. Evolution structural de la region de L'Espinhafo Meridional, bordure sud-est du Craton São Francisco, Bresil: tectoniques superposees au Proterozoi'que. UniversitS d'Orteans, Orleans, France, $\mathrm{PhD}$ thesys, $191 \mathrm{p}$

Eby, G.N. 1992. Chemical subdivision of the A-type granitoids: petrogenetic and tectonic implications. Geology, 20: 641-644

Faria, L.F. de 1997. Controle e tipologia de mineralizacoes de grafita flake do nordeste de Minas Gerais e sul da Bahia: uma abordagem regional. Inst. Geociências, Universidade Federal de Minas Gerais, Belo Horizonte, Brazil, MSc thesis, 102 p.

Fernandes, M.L.S. 1991. Geologia petrografia e geoqmmica de rochas granitoides da regiao de Pedra Azul, MG. Inst. Geociências, Universidade Federal do Rio de Janeiro, Brazil, MSc thesis, $191 \mathrm{p}$.

Figueiredo, M.C.H. \& Teixeira, W. 1996. The Mantiqueira Metamorphic Complex, eastern Minas Gerais State: preliminary geochronological and geochemical results. An. Acad.bras.Ci.,6Z: 1-24

Grossi-Sad, J.H.; Lobato, L.M.; Pedrosa-Soares, A.C.; Soares-Filho, B.S. (ed.) 1997. Projeto Espinhaco em CD-ROM. Belo Horizonte, Brazil, Companhia Mineradora de Minas Gerais, 2693 p.

Haralyi, N.L.E. \& Hasui, Y. 1982. The gravimetric information and the Archean-Proterozoic Structural Framework of Eastern Brazil. Rev. Bras. Geociências, 12: 160-166

Harris, N.B.W.; Pearce, J.A.; Tindle, A.G. 1986. Geochemical characteristics of collision-zone magmatism. Geol. Soc. Special Publ., 19: 67-81

Irvine, T.N. \& Baragar, W.R. A. 1971. A guide to the chemical classification of the common volcanick rocks. Can. J. Earth Sci., 8: 523-548

Leonardos, O.H. \& Fyfe, W.S. 1974. Ultrametamorphism and melting of a continental margin: the Rio de Janeiro region, Brasil. Contr. Mineral. Petrol., 46: 201-214

Litwinski, N. 1985. Evolufuo tectono-termal da regiao nordeste de Minus Gerais e sul da Bahia. Inst. Geociências, Universidade de São Paulo, São Paulo, Brazil, $\mathrm{PhD}$ thesis, $207 \mathrm{p}$.

Monteiro, R.L.B.P.; Leonardos, O.H.; Correia-Neves, J.M. 1990. An epigenetic origin for the new scheelite and wolframite occurrences in the Middle Jequitinhonha Valley, Minas Gerais, Brazil. Rev. Bras. Geociências, 20: 68-74

Nalini Jr., H.A.; Bilal, E.; Paquette, J.L.; Correia-Neves, J.M.; Carneiro, M.A. 1997. U-Pb zircon geochronology and typology from two Neoproterozoic granitoid suites of the Rio Doce valley, eastern State of Minas Gerais, Brazil. In: SBG, Int. Symp. on Granites and Associated Mineralizations, 2, Salvador, Brazil, Extended Abstracts, 265-266

Nalini Jr., H. A.; Bilal, E.; Correia-Neves, J.M.; Carneiro, M.A. 1996. Evidencias da contribuic. ao crustal a partir do estudo tipoldgico de zircoes nos granitoides da regiao do Mddio Rio Doce, Minas Gerais. In: SBG, Congr. Bras. Geol., 39, Salvador Anais... Salvador, SBG, v. 6, p. 418-420

Noce, C.M.; Pedrosa-Soares, A.C.; Grossi-Sad, J.H.; Baars, F.J.; Guimaraes, M.L.V.; Mourao, M.A.A.; Oliveira, M.J.R.; Roque, N.C. 1997. Nova subdiviSão estratigraTica regional do Grupo Macaiibas na Faixa Arac. uai: o registro de umabacia neoproteroz6ica. In: SBG-Nucleo Minas Gerais, Simp. Geol. Minas Gerais, 9, Ouro Preto, Anais, 29-31

Pearce, J. 1996. Sources and settings of granitic rocks. Episodes 19: 120-125

Pearce, J.A., Harris, N.B.W.; Tindle, A.G. 1984. Trace element discrimination diagrams for the tectonic interpretation of granitic rocks. J. Petrol., 25: 956-983

Pedreira, A.J.; Vieira, V.S.; Signorelli, N. 1997. Turbiditos do setor oriental da Faixa Ara\&uai, Minas Gerais. A Terra em Revista, 3: 28-33

Pedrosa-Soares, A.C. 1997a. Geologia da Folha Arafuai. In: J.H. Grossi-Sad; L.M. Lobato; A.C. Pedrosa-Soares; B.S. Soares-Filho (ed.), Projeto Espinhaco em CD-ROM. Belo Horizonte, Brazil, Companhia Mineradora de Minas Gerais, 715-852

Pedrosa-Soares, A.C. 1997b. Geologia da Folha Jenipapo. In: J.H. Grossi-Sad; L.M Lobato; A.C. Pedrosa-Soares; B.S. Soares-Filho (ed.), Projeto Espinhaco en CD-ROM. Belo Horizonte, Brazil, Companhia Mineradora de Minas Gerais, 1053-1198
Pedrosa-Soares, A.C. 1996. O setor setentrional da Faixa Ara?uaf. In: SBG, Congr. Bras. Geol., 39, Salvador, Roteiros de Excursoes, ExcurSão E-12: 13-49

Pedrosa-Soares, A.C. 1995. Potencial aurifero do Vale do Araçuaí, MG: historia da explorucao, geologia e controle tectono-metamorftco. Inst. Geociências, Universidade de Brasilia, Brasilia, $\mathrm{PhD}$ thesis, $177 \mathrm{p}$

Pedrosa-Soares, A.C. \& Oliveira, M.J.R. 1997. Geologia da Folha Salinas. In: J.H. Grossi-Sad; L.M. Lobato; A.C. Pedrosa-Soares; B.S. Soares-Filho (ed.), Projeto Espinhaco em CD-ROM. Belo Horizonte, Brazil, Companhia Mineradora de Minas Gerais, 419-542

Pedrosa-Soares, A.C. \& Siga Jr., 0.1987. Geoqufmica, geocronologiaegenesedos granitos de Coronel Murta, Minas Gerais. In: SBGq, Congr. Bras. Geoqufmica, 1, Porto Megre, Anais, 1: 141-152

Pedrosa-Soares, A.C. Vidal, Ph. Leonardos, O.H. Brito-Neves, B.B. 1997. Neoproterozoic oceanic remnants in eastern Brazil: further evidence and refutation of an exclusively ensialic evolution for the Arafuaf-West Congo Orogen. (submitted to Geology).

Pedrosa-Soares, A.C.; Leonardos, O.K.; Ferreira, J.C.H.; Reis, L.B. 1996. Duplo regime metamorfico regional na Faixa Araçuaí(?): uma reavaliacao a luz de novos dados. In: SBG, Congr. Bras. Geol., 39, Salvador, Anais, 6: 5-8

Pedrosa-Soares, A.C.; Dardenne, M.A.; Hasui, Y.; Castro, F.D.C.; Carvalho, M.V.A.; Reis, A.C. 1994a. Mapa Geologico do Estado de Minus Gerais, escala 1:1.000.000. Belo Horizonte, Brazil, Companhia Mineradora de Minas Gerais.

Pedrosa-Soares, A.C.; Dardenne, M.A.; Hasui, Y.; Castro, F.D.C.; Carvalho, M.V.A. 1994b. Nota Explicativa dos Mapas Geologico, Met alogenetico e de Ocorrencias Minerals do Estado de Minas Gerais. Belo Horizonte, Brazil, Companhia Mineradora de Minas Gerais, $97 \mathrm{p}$.

Pedrosa-Soares, A.C.; Noce, CM.; Vidal, Ph.; Monteiro, R.L.B.P.; Leonardos, O.H. 1992. Toward a new tectonic model for the Late Proterozoic Araçuaí (SE Brazil)-West Congolian (SW Africa) Belt. J. South Amer. Earth Sci., 6: 33-47

Pedrosa-Soares, A. C; Correia-Neves, J.M. \& Leonardos, O.H. 1990. Tipologia dos pegmatitos de Coronel Murta-Virgem da Lapa, M6dio Jequitinhonha, Minas Gerais. Revista Escola de Minas, 43: 44-59

Pedrosa-Soares, A.C.; Monteiro, R.L.B.P.; Correia-Neves, J.M.; Leonardos, O.H.; Fuzikawa, K. 1987. Metasomatic evolution of granites, northeast Minas Gerais, Brazil. Rev. Brus. Geociências, 17: 512-518 (Errata for geochemical data tables in v. 18, p. 319. 1988)

Pinto, C.P.; Drumond, J.B.V.; Feboli, W.L. (coord.) 1997. Projeto Leste: mapeamento geologico, cadastramento de recursos minerals da regiao leste de Minas Gerais Etapa I. Belo Horizonte, Brazil, Companhia de Pesquisa de Recursos Minerals, 161 P-

Pitcher, W.S. 1993. The nature and origin of granite. London, Chapman and Hall, 321 p.

Roberts, M.P. \& Clemens, J.D. 1993. Origin of high-potassium, calc-alkalic, I-type granitoids. Geology, 21: 825-828

Schobbenhaus, C. 1996. As tafrogeneses superpostas Espinhac.o e Santo Onofre, Estado da Bahia: reviSão e novas propostas. Rev. Bras. Geociências, 26: 265-276

Schobbenhaus, C.; Campos, D.A.; Derze, G.R.; Asmus, H.E. (coord.) 1981. Mapa Geologico do Brasil e da Area Ocednica adjacente, incluindo depositos minerals, escala 1:2.500.000. Brasilia, Departamento Nacional da Produfao Mineral.

Shand, S.F. 1943. Eruptive rocks. New York, Willey and Sons.

Siga Jr., O. 1986. A evolufao geocrono! 6gica da por?ao nordeste de Minas Gerais, com base em interpretafoes geocrono!6gicas. Inst. Geociências, Universidade de São Paulo, São Paulo, Brazil, MSc thesis, 140 p.

Silva, J.M.R.; Lima, M.I.C.; Veronese, V.F.; Ribeiro Jr., N.; Rocha, R.M.; SIGA Jr., O. 1987. Geologia. In: SEPLAN-Funda9ao IBGE, Rio de Janeiro, Brazil. Levantamento de Recursos Naturals; Folha SE.24-Rio Doce, 34: 23-172

Trompette, R, 1994. Geologv of Western Gondwana (2000-500 Ma). Amsterdam, Balkema, $350 \mathrm{p}$.

Uhlein, A.; Trompette, R.; Egydio-Silva, M. 1995. Rifteamentos superpostos e tectonica de inverSão na borda sudeste do CrSton do São Francisco. Geonomos, 3: 99-107

Ussami, N. \& Sa, N. C. 1993. Digital (10' x 10') gravity maps of the São Francisco Craton and marginal fold-thrust belts. In: SBG-Nucleo Bahia, Simp. CrSton do São Francisco, 2. Salvador, Anais, 137-139

Wiedemann, C. 1996. Os arcos magmSticos pre- a p6s-colisionais da orogenia brasiliana na borda leste do Craton do São Francisco. Bol. Inst. Geociências USP, Sp. Publ., 18:79-81

Wiedemann, C. 1993. The evolution of the Early Paleozoic, late to post-collisional magmatic arc of the Coastal Mobile Belt, in the State of Espirito Santo, eastern Brazil. An. Acad. bras. Ci., 65 (supl. 1): 163-181

Wilson, M. 1989. Igneous Petrogenesis. London, Unwin Hyman, 466 p.

Manuscrito A-1052

Recebido em 10 de Janeiro de 1998 ReviSão dos autores em 30 de maio de 1998 ReviSão aceita em 15 de junho de 1998 